\title{
Libraries without walls 7
}

\section{Project StORe \\ - expectations, a solution \\ and some predicted impact from \\ opening up the research data portfolio}

Graham Pryor 


\section{Libraries without walls 7}

\section{StORe guide}

- Libraries and the research agenda

- The StORe project

- Objectives

- Results from a survey

- Support and self-determination

- The challenge for librarians? 


\section{Libraries without walls 7}
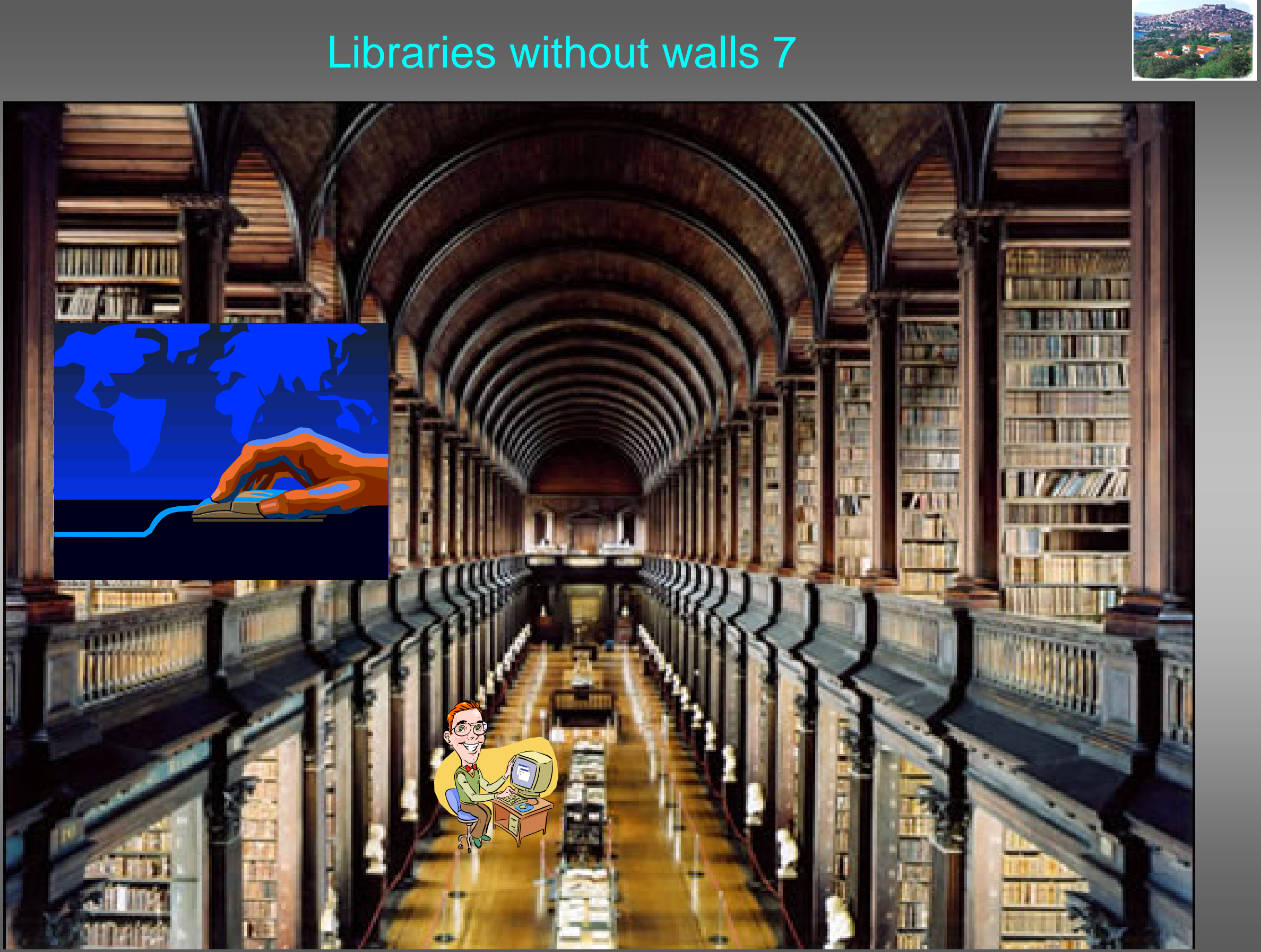


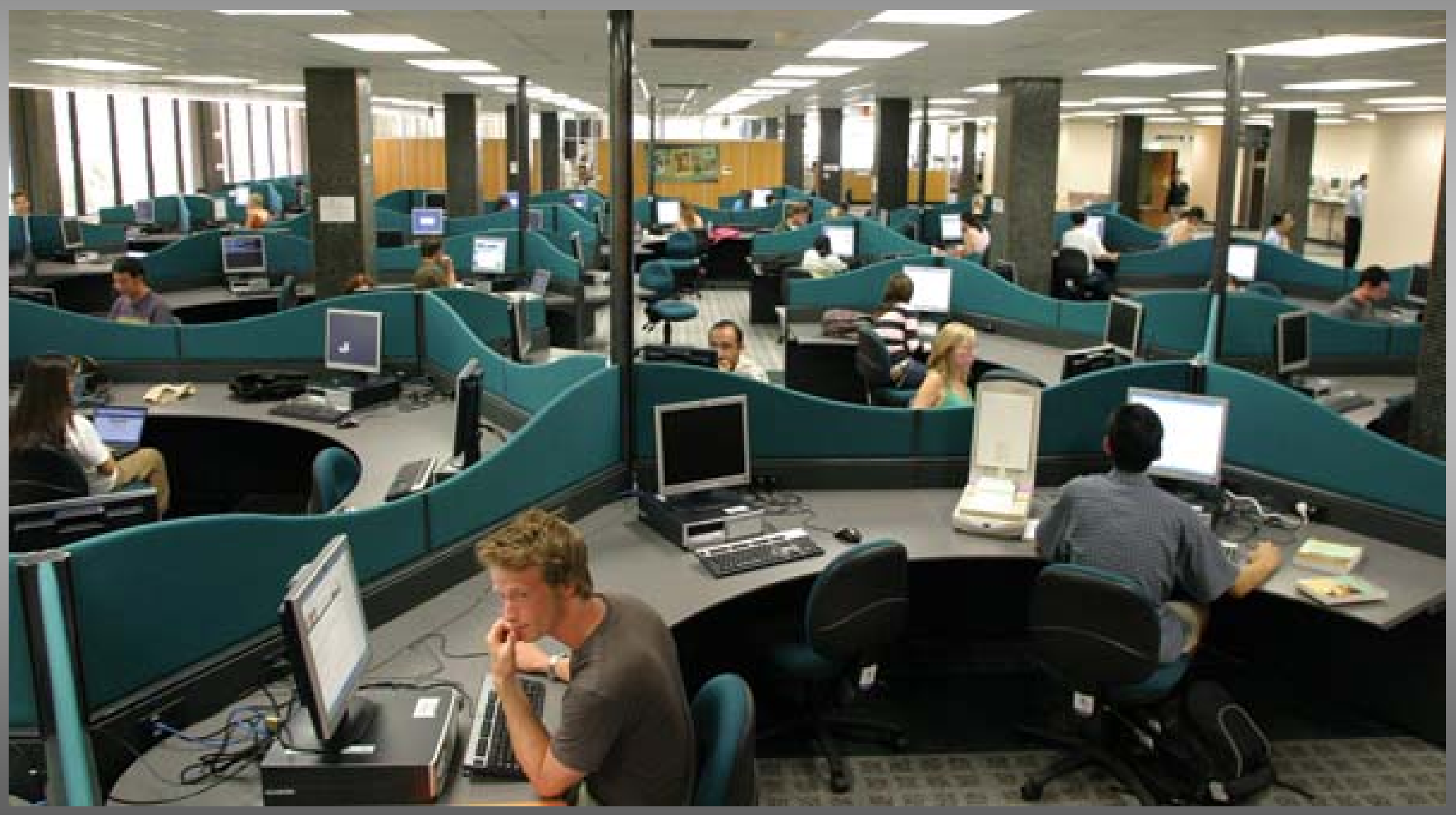




\section{Libraries without walls 7}

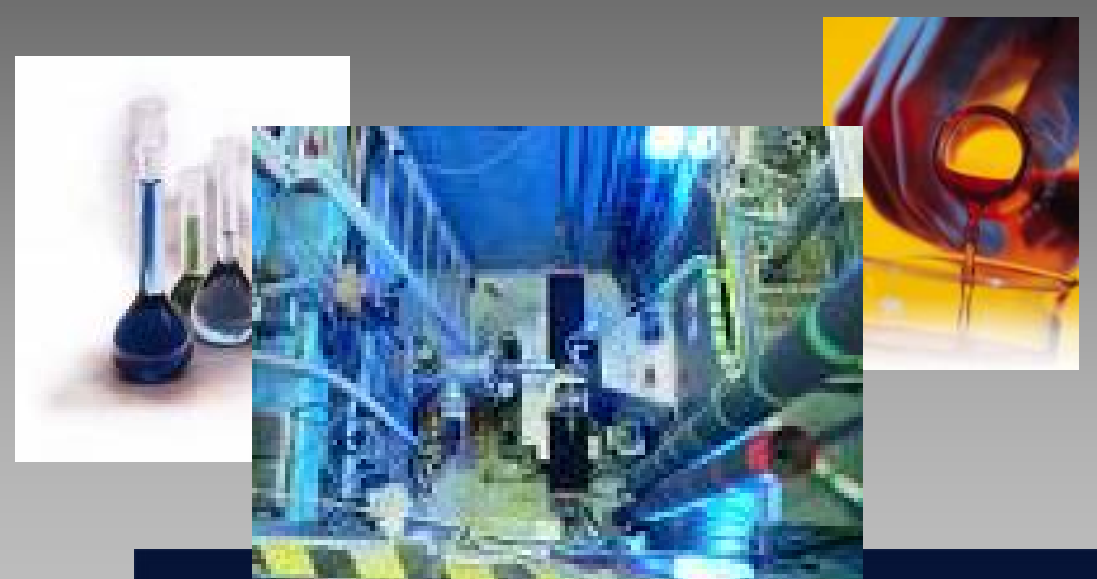

$£ 3,000,000,000$ current annual investment - UK Research Councils

\section{Challenges in Internet Anomaly Detection}
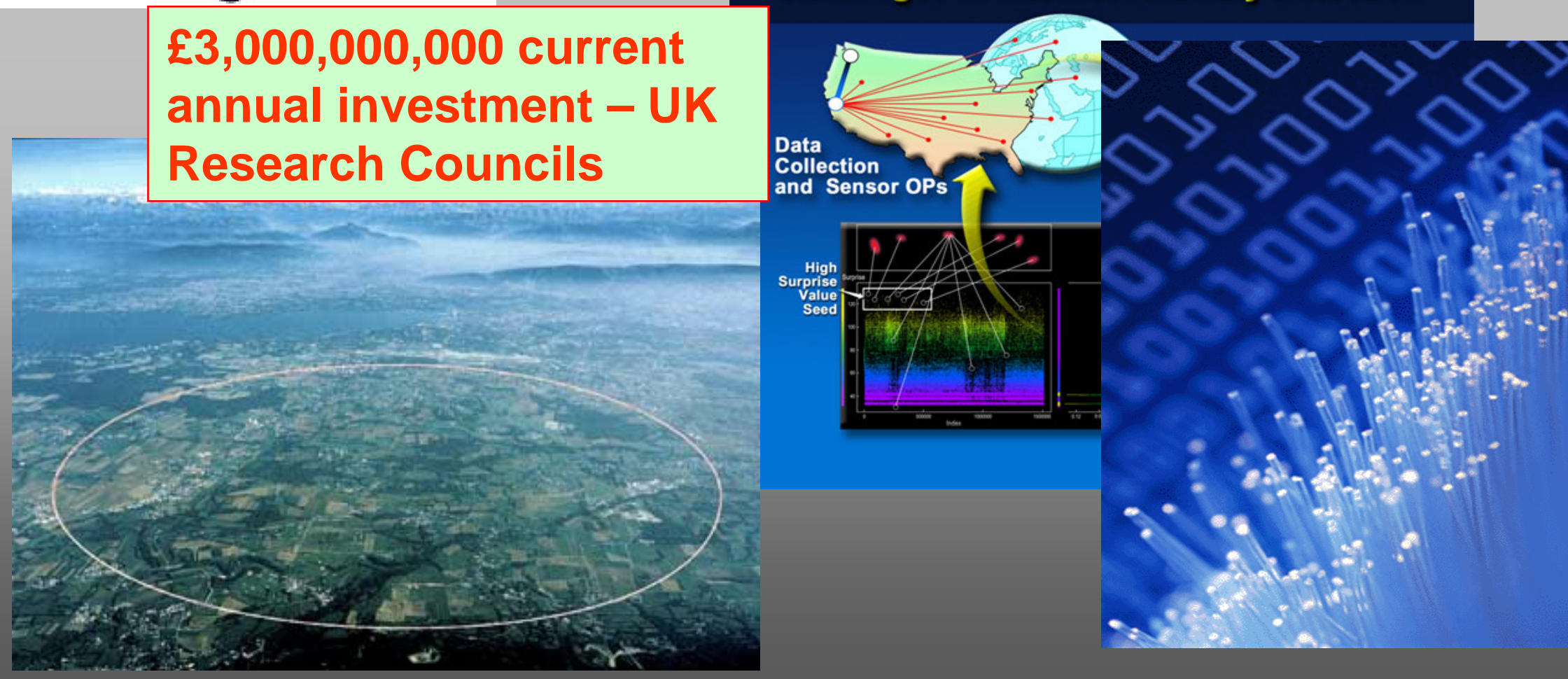


\section{Libraries without walls 7}

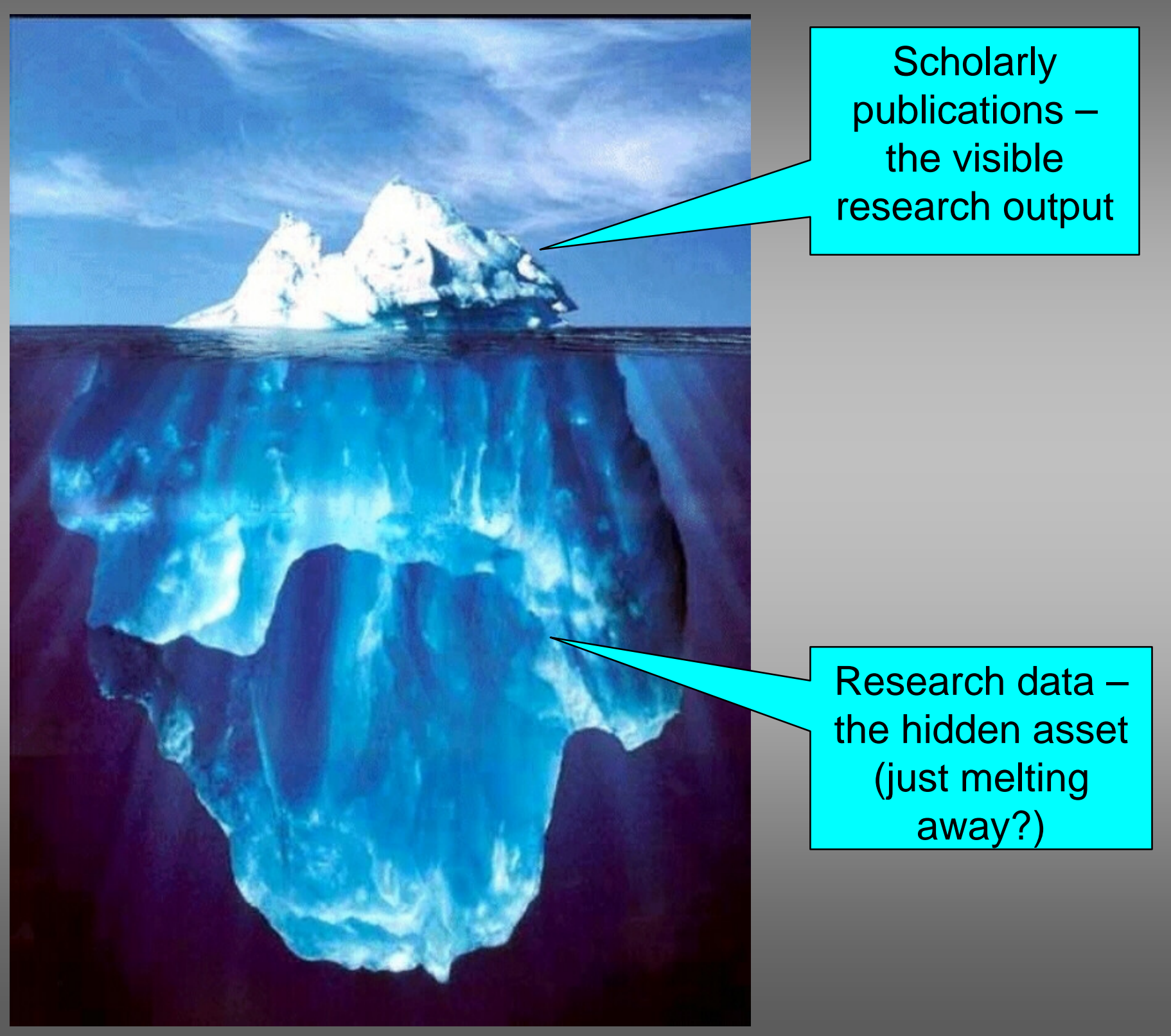




\section{Libraries without walls 7}

The pencil is mightier than the pen

- Robert M Pirsig, Lila - an inquiry into morals

- Science as provisional

- Contains a mechanism "whereby new dynamic insight can wipe out old static patterns without wiping out science itself"

- Enables continuous evolutionary growth 


\section{Libraries without walls 7}

\section{The pencil is mightier than the pen}

\section{The computer is mightier than the printing press}

So, the next stage in the evolutionary growth of science librarians will be...? 


\section{Libraries without walls 7}

\section{Political landscape}

- Open access movement - the Berlin, Budapest and other declarations

- Wellcome Trust

- Funding linked to commitment to deposit

- UK Research Councils - data policies

- Publicly funded research data a public good

- Appropriate curation throughout the lifecycle

- Need for high quality metadata 


\section{Libraries without walls 7}

The StORe mission

- Seamless transport from research data to research publications and vice versa

- Bi-directional links proven in social science e-research but capable of export to other disciplines

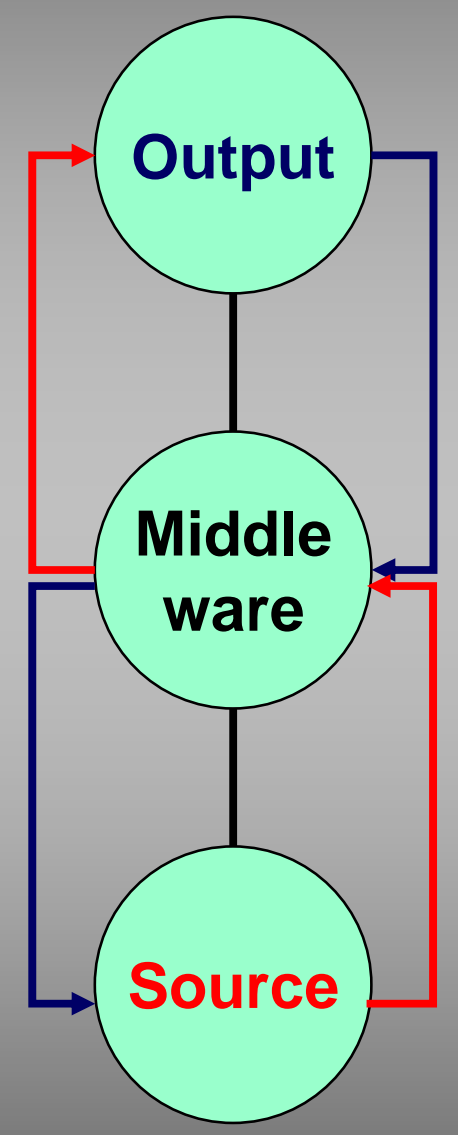




\section{Libraries without walls 7}

SuperCOSMOS Science Archive - Microsoft Internet Ex Edinburgh Research Archive : Home - Microsoft Internet Explorer

File Edit Yiew Favorites Tools Help File Edit Wiew Favorites Tools Help

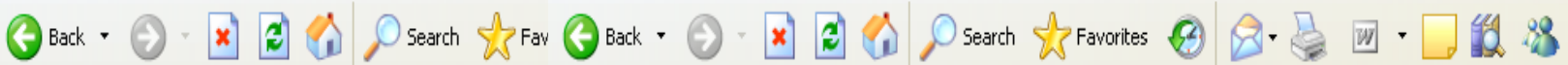

Address 6 http://surveys,roe,ac,ukj/ssal

\section{Supercosmos \\ Science \\ Archive}

SSA Home

Data Overview

Schema browser

Data access

Radial

Menu query

Freeform SQL

Crossid

Cookbook

Personal SSA

Q8A

Release History

Downtime

Links

Credits

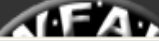

Done

\section{SSA - SuperC}

The SuperCOSMOS survey plates.

At around 2.5 terabyte over 1 billion multi-colo wavebands (BR)), with based on the same und platform allows users $n$

A short description of $t$ Schema Browser.

Users wishing to acce

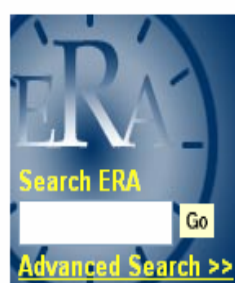

Not logged in (Login)

Welcome to the Edinburgh Research Archive

Welcome to ERA, a digital repository of research output from The University of Edinburgh. Contained here are full-text digital Theses and Dissertations, book chapters, journal pre-prints and peer-reviewed journal reprints.

\section{Search}

\section{Browse \\ Communities}

$\underline{\text { \& Collections }}$

- Titles

- Authors

By Date

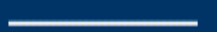

\section{Sign on to:}

- Receive email

upgdates

- My ERA

authorized users

- Edit Profile

Edinburgh Research Archive >

Enter some text in the box below to search ERA.

\section{Go}

Or go to the Advanced Search

\section{Browse}

- Communities \& Collections

- by Title

- by Author

- by Date

\section{Depositing ltems}

\section{Edinburgh Research Archive}

Learn how to deposit your items in ERA: Read the Deposit Guide

\section{Copyright}

Not sure of the Publishers copyright policy to archiving your journal articles online? Use these sites to find a summary of permissions

that are normally given as part of each publisher's copyright transfer agreement.

By Journal Publisher: http://www. sherpa.ac.uk/romeo. php

By Journal Title: hitp://romeo.eprints. orgl

Similarly, if you are submitting an electronic thesis to ERA you may be worried that you are violating publishers' publication policies for future journal articles you may wish to publish. You can check the database of links to publishers' journal policies called the Academic Journal Policy Database (A.JP):

http://wwww. etd.uc.edu/journal/

\section{Mediated Deposit}

Are you or your department too busy to archive all nf vonur material in the Fodinhurrah Researr.h 


\section{Libraries without walls 7}

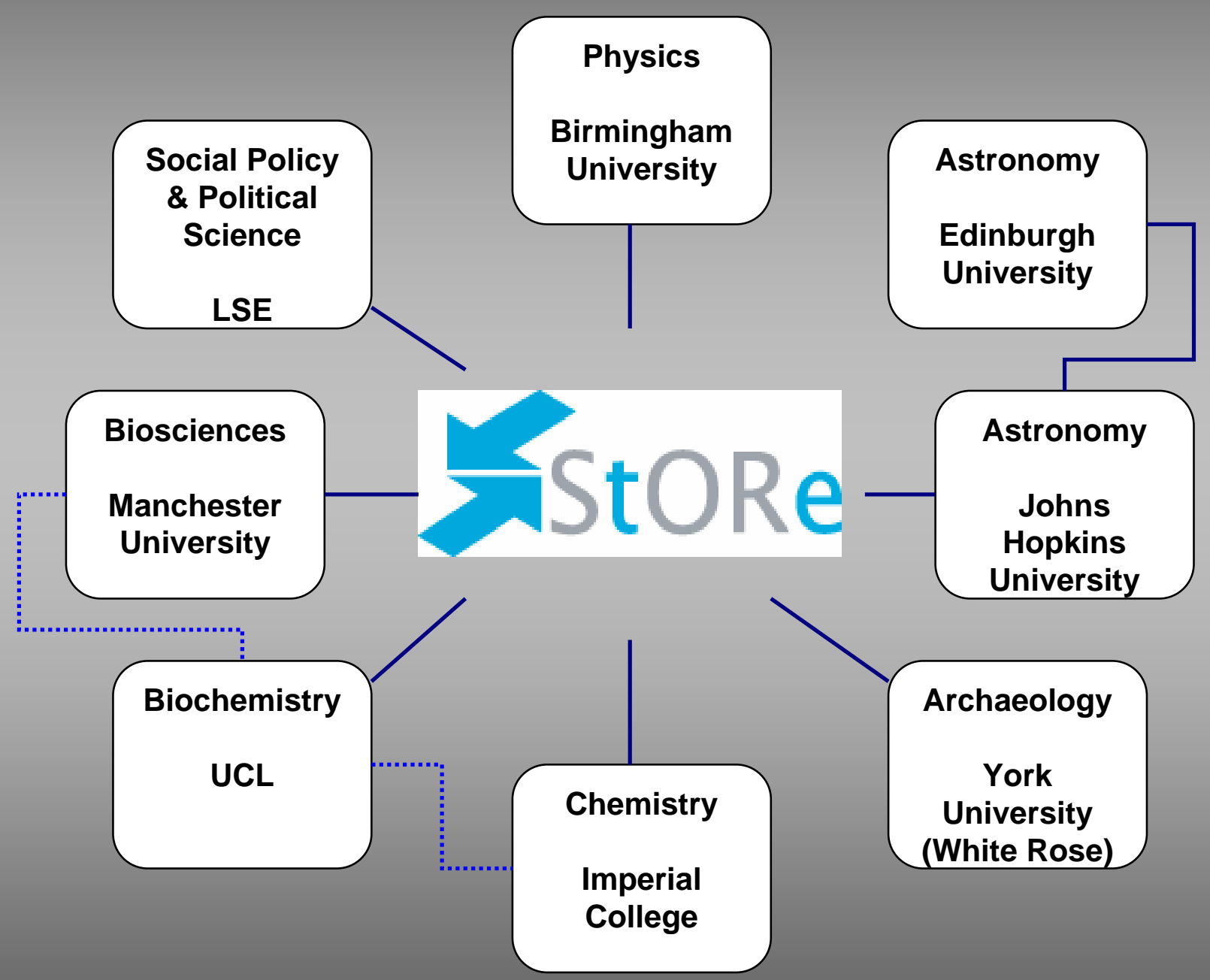

7 domains

surveyed for data management and research process

Library origins of project experience with generic tools and protocols

\section{Survey} team: library and domain expertise 


\section{Libraries without walls 7}

\section{New opportunities New risks}

- Explore a deeper level of detail

- Supplement published papers

- Validate experiments

- Track the use and improvement of research output

- Identify collaborators

- Confirm completeness of information searches
- Uncertainty of peer review

- Premature dissemination

- Subversion of scholarly paper

- Scavenging

- Lack of interpretative data 


\section{Libraries without walls 7}

\section{StORe survey}

- $85 \%$ approved aims as likely to prove advantageous

- Questionable data management practices and a metadata conflict

- Tension between open access and data ownership 


\section{Libraries without walls 7}

\section{Data management}

Common practice of storing unique and original research data on the hard drives of PCs and laptops (especially prevalent in chemistry and the biosciences)

"Once removed from the computers I hold the only available copies of most of my data" 


\section{Libraries without walls 7}

\section{Metadata - researchers identified}

- The need for improved and universal standards

- A need for different metadata for different phases of the research lifecycle (raw, processed, published data and beyond)

- A clear link between the condition of metadata used and the level of support from information specialists 


\section{Libraries without walls 7}

\section{The assignment of metadata}

\begin{tabular}{|l|l|l|}
\hline $\begin{array}{l}\text { I decide which terms to use and I assign } \\
\text { them: }\end{array}$ & 212 \\
\hline $\begin{array}{l}\text { Research colleague(s) assign metadata on the } \\
\text { team's behalf: }\end{array}$ & - & 55 \\
\hline $\begin{array}{l}\text { Research support staff assign metadata on } \\
\text { the team's behalf: }\end{array}$ & {[} & 22 \\
\hline $\begin{array}{l}\text { Metadata are assigned by librarylinformation } \\
\text { services staff: }\end{array}$ & {[} & 4 \\
\hline $\begin{array}{l}\text { Metadata are assigned by the repository } \\
\text { administrators: }\end{array}$ & - & 37 \\
\hline Metadata are generated automatically: & - & 63 \\
\hline It is not known who assigns metadata: & - & 68 \\
\hline Other (please specify): & - & 37 \\
\hline
\end{tabular}




\section{Libraries without walls 7}

\begin{tabular}{|l|c|c|c|c|c|c|c|}
$\begin{array}{l}\text { Types of } \\
\text { support } \\
\text { used }\end{array}$ & $\begin{array}{c}\text { Academi } \\
\text { c staff }\end{array}$ & $\begin{array}{c}\text { Researc } \\
\mathbf{h} \\
\text { assistan } \\
\mathbf{t}\end{array}$ & $\begin{array}{c}\text { Post- } \\
\text { graduate }\end{array}$ & $\begin{array}{c}\text { Contract } \\
\text { research } \\
\text { er }\end{array}$ & $\begin{array}{c}\text { Independen } \\
\text { tresearcher }\end{array}$ & Other & Totals \\
\hline $\begin{array}{l}\text { Documentar } \\
\text { y support }\end{array}$ & 29 & 5 & 16 & 6 & 2 & 8 & 66 \\
\hline $\begin{array}{l}\text { Support by } \\
\text { intermediary }\end{array}$ & 16 & 2 & 7 & 1 & 0 & 3 & 29 \\
\hline $\begin{array}{l}\text { Repository- } \\
\text { enabled } \\
\text { support }\end{array}$ & 56 & 5 & 7 & 5 & 1 & 9 & 83 \\
\hline $\begin{array}{l}\text { No support } \\
\text { is provided }\end{array}$ & 60 & 7 & 23 & 4 & 3 & 9 & 106 \\
\hline Unknown & 31 & 11 & 25 & 1 & 1 & 9 & 78 \\
\hline Other & 5 & 1 & 4 & 1 & 0 & 3 & 14 \\
\hline No Answer & 0 & 0 & 1 & 0 & 0 & 0 & 1 \\
\hline Totals & 197 & 31 & 83 & 18 & 7 & 41 & 377 \\
\hline
\end{tabular}




\section{Libraries without walls 7}

\begin{tabular}{|c|c|c|c|c|c|c|c|}
\hline $\begin{array}{l}\text { Assistance } \\
\text { by library or } \\
\text { IS staff }\end{array}$ & $\begin{array}{l}\text { Academi } \\
\text { c staff }\end{array}$ & $\begin{array}{l}\text { Researc } \\
\mathbf{h} \\
\text { assistan } \\
\mathbf{t}\end{array}$ & $\begin{array}{c}\text { Post- } \\
\text { graduate }\end{array}$ & $\begin{array}{l}\text { Contract } \\
\text { Research } \\
\text { er }\end{array}$ & $\begin{array}{l}\text { Independen } \\
\text { t researcher }\end{array}$ & Other & Totals \\
\hline $\begin{array}{l}\text { Documentary } \\
\text { (guidance } \\
\text { notes etc.) }\end{array}$ & 61 & 6 & 24 & 5 & 4 & 9 & 109 \\
\hline $\begin{array}{l}\text { Formal } \\
\text { training }\end{array}$ & 38 & 3 & 27 & 3 & 0 & 3 & 74 \\
\hline $\begin{array}{l}\text { Online or } \\
\text { telephone } \\
\text { Heln }\end{array}$ & \multirow{2}{*}{\multicolumn{5}{|c|}{$\begin{array}{l}\text { "...my university assigned a librarian to } \\
\text { our department but I have not used her } \\
\text { services..." }\end{array}$}} & 5 & 89 \\
\hline $\begin{array}{l}\text { structuring } \\
\text { searches }\end{array}$ & & & & & & 1 & 26 \\
\hline $\begin{array}{l}\text { Help in the } \\
\text { conduct of } \\
\text { searches }\end{array}$ & 20 & 4 & 11 & 3 & 0 & 4 & 42 \\
\hline $\begin{array}{l}\text { Fully managed } \\
\text { intermediation } \\
\text { (searches and } \\
\text { results ) }\end{array}$ & 3 & 2 & 5 & 0 & 0 & 1 & 11 \\
\hline Unknown & 83 & 19 & 34 & 8 & 3 & 21 & 168 \\
\hline
\end{tabular}




\section{Libraries without walls 7}

\section{The research culture - a broad perspective}

- Self-reliance and tradition of individual research endeavour

- "No assistance required - it's my responsibility"

- "I rely on my own skills"

- Protection of research profile or status

- "Data archives would become the preserve of the scavengers, unable to generate their own research ideas"

- "The most important factors are those that would benefit my research profile"

- Conflict between a competitive environment and the aspiration to collaborate

- "The competition for publication is intense and would not be aided by making data freely available"

- "It should be a requirement for publicly funded research that data be made available" 


\section{Libraries without walls 7}

Factors that discourage the sharing of research

\begin{tabular}{|c|c|c|}
\hline threat of I & 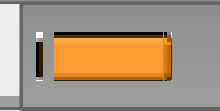 & 202 \\
\hline Risks to an established research niche & 口 & 104 \\
\hline $\begin{array}{l}\text { Risk of premature broadcast of research } \\
\text { findings }\end{array}$ & $1=$ & 235 \\
\hline $\begin{array}{l}\text { Subversion of intellectual property rights } \\
\text { including copyright }\end{array}$ & $\square$ & 163 \\
\hline Ehical constraints relating to my research & 0 & 58 \\
\hline $\begin{array}{l}\text { Consideration of data protection and other } \\
\text { confidentiality issues }\end{array}$ & 口 & 115 \\
\hline The time/ effort required to enable sharing & $=$ & 193 \\
\hline $\begin{array}{l}\text { Risk of diversion from principal objectives } \\
\text { through the generation of additional work }\end{array}$ & 门 & 144 \\
\hline Risk to commercialisation opportunities & 1. & 59 \\
\hline Increased competition for funding & $\square$ & 77 \\
\hline
\end{tabular}




\section{Libraries without walls 7}

\section{The StORe team concluded that}

- Data sharing is a fundamental principle of research, but...

- It is conducted mainly through private networking, with $>50 \%$ through the personal exchange of e-mails or portable media

- Bureaucratic processes and organisations are anathema to researchers

- Both standards and simplicity are sought for research data management (esp. for metadata)

- Assisted self management is preferred to overt intermediation 


\section{Libraries without walls 7}

\section{Design for the StORe middleware}

- Web 2.0 approach, similar to services like Flickr or MySpace, gives control to the researcher

- Researchers determine which items are public / private

- Researchers form collaborations with colleagues / 'friends'

- Researchers select items for deposit and for publication

- Based on federations of institutional repositories and data archives

- Permanent links created between publications and underlying data

- Simple process for assignment of metadata

- Searchable metadata assigned at collection level inherited by items within the collection

- Collection owners add individual items plus minimum additional metadata (e.g. titles) 


\section{Libraries without walls 7}

5 StORe

Source-to-Output Repositories

Home | Logout | About StoRe | Administration Search for All Public Collections $v$ Search Adv. Seart

\begin{tabular}{|l|l|l|l|l|}
\hline All Collections & My Collections & Collaborative Collections & Approval queue & Profile \\
\hline
\end{tabular}

Item: Business Analysis

\section{The StORe pilot federation}

\section{Collection: Edinburgh}

Yiew Item Edit Item

\begin{tabular}{|c|c|c|c|}
\hline \multirow{2}{*}{$\begin{array}{l}\text { Dublin Core } \\
\text { w }\end{array}$} & \multicolumn{2}{|l|}{ EDIT } & \\
\hline & \multicolumn{2}{|c|}{ * Denotes required fields } & \\
\hline & ${ }^{*}$ Title: & Business Analysis & \\
\hline \multirow{3}{*}{$\frac{\text { StOReBusinessanalysis }}{\text { (application/msword) }}$} & Creator: & Ken & \multirow{3}{*}{$\begin{array}{l}\text { Add Creator Field } \\
\text { Add Subiect Field }\end{array}$} \\
\hline & *Subject: & pilot & \\
\hline & *Subject: & presentation & \\
\hline Add File or & & $\begin{array}{l}\text { A collaborative collection } \\
\text { the pilot demonstration in }\end{array}$ & $\begin{array}{l}\text { that I might } \\
\text { Edinburgh }\end{array}$ \\
\hline
\end{tabular}

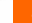

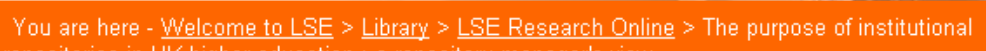

The purpose of institutional repositories in UK higher education : a repository manager"s view

UK Data Archive

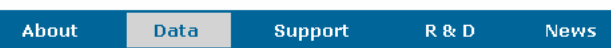

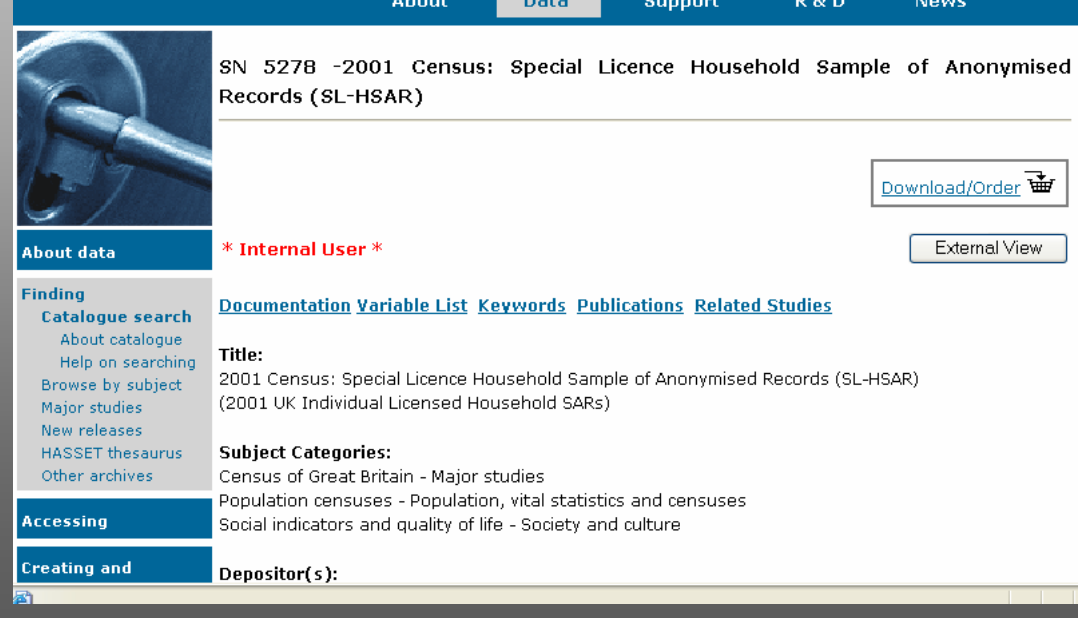

Rumsey, Sally (2006) The purpose of institutional repositories in UK higher education : a repository manager's view. International journal of information management, 26 (3). pp. 181-186. ISSN 02684012

Full text available as:

$\frac{\mathrm{P}}{\mathrm{PDF}}$ PDF - Requires Adobe Acrobat Reader or other PDF viewer.

Abstract

Open access publications may be a means of increasing availability of scholarly materials. However, there are other drivers which prompt $\mathrm{HE}$ institutions to spend staff time and investment on developing IRs. If the publishing arguments are put to one side, there is a separate and strong case for developing an IR which is justified by a library's functions of collecting, managing and curating materials.

Additional Information: Published 2006 (1) Elsevier B.V. LSE has developed LSE Research Online so that users may access research output of the School. Copyright and Moral Rights for the papers on this site are retained by the individual authors and/or other copyright owners. Users 


\section{Libraries without walls 7}

\section{Source-to-Output Repositories}

Search for

\section{Collection:}

\section{Madiera}

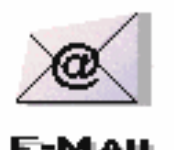

E-MAIL

Email Owner

\begin{tabular}{|r|r|}
\hline Creator & Ken \\
\hline Subject & data portal, multilingual thesaurus, online data analysis \\
\hline Description & Multilingual Access to Data Infrastructures of the European Research Area \\
\hline Contributor & \\
\hline Date \\
\hline Type \\
\hline Format \\
\hline Identifier \\
\hline Source \\
\hline Language \\
\hline Relation \\
\hline Roverage & \\
\hline Rights & \\
\hline Type of Research & Primary from Secondary (Creates new data based on existing data) \\
\hline Data Repository & UKDA \\
\hline Study & 4995 \\
\hline Contributors & \\
\hline
\end{tabular}




\section{Libraries without walls 7}

StORe

Source-to-Output Repositories

Home | Logout | About StoRe | Administration Search for All Public Collections $\vee$ Search Adv. Search

\begin{tabular}{|l|l|l|l|l|}
\hline All Collections & My Collections & Collaborative Collections & Approval queue & Profile \\
\hline
\end{tabular}

Item: Business Analysis

\section{Collection: Edinburgh}

\begin{tabular}{|l|l}
\hline View Item Edit Item \\
\hline
\end{tabular}

\begin{tabular}{|c|c|c|c|c|}
\hline \multirow{2}{*}{ Dublin Core } & \multicolumn{3}{|l|}{ EDIT } & \multirow[t]{2}{*}{$\begin{array}{l}\text { ADD } \\
\text { SuBJECt } \\
\text { TAGS }\end{array}$} \\
\hline & *Title: & Business Analysis & & \\
\hline \multirow{3}{*}{$\begin{array}{l}\text { StoReBusinessAnalysis } \\
\text { (application/msword) }\end{array}$} & Creator: & Ken & Add Creator Field & \multirow{8}{*}{\begin{tabular}{|l|} 
books \\
crime \\
demonstrator \\
email \\
health \\
health subject \\
pilot \\
presentation \\
repositories data publications linkage \\
subject
\end{tabular}} \\
\hline & *Subject: & pilot & Add Subject Field & \\
\hline & *Subject: & presentation & & \\
\hline \multirow[t]{2}{*}{$\begin{array}{l}\text { Add File or } \\
\text { Link }\end{array}$} & Description: & $\begin{array}{l}\text { A collaborative collection } \\
\text { the pilot demonstration in }\end{array}$ & $\begin{array}{l}\text { that I might use in } \\
\text { Edinburgh }\end{array}$ & \\
\hline & Publisher: & Ken Miller & Add Publisher Field & \\
\hline \multirow[t]{14}{*}{ Move Item } & Contributor: & & Add Contributor Field & \\
\hline & Date: & $07 / 11 / 2006$ & Add Date Field & \\
\hline & Type: & & Add Type Field & \\
\hline & Format: & & Add Format Field & \\
\hline & Identifier: & & Add Identifier Field & \multirow[t]{10}{*}{ Add Selected } \\
\hline & Source: & & Add Source Field & \\
\hline & Language: & English & Add Lanquaqe Field & \\
\hline & Relation: & & Add Relation Field & \\
\hline & Coverage: & & Add Coverage Field & \\
\hline & Rights: & & Add Rights Field & \\
\hline & $\begin{array}{l}\text { *Type of } \\
\text { Research: }\end{array}$ & Secondary Analysis (Based on existing data) & $\checkmark$ & \\
\hline & Study: & 4800 & UK Data Archive & \\
\hline & & Add Study Field & & \\
\hline & Make Change & & & \\
\hline
\end{tabular}




\section{Libraries without walls 7}

\section{Roles, Rights, Responsibilities, Relationships - 1}

-Institutional Repositories tend to be managed by 'generalists' located in libraries and information services, and usually lacking data skills

-Subject repositories are staffed by domain experts with well-developed data handling skills

-Data sets tend to be unique

- are deposited without multiple copies

- are not self-describing and may

- require interpretation, particular competencies and domain knowledge

-Representation information, which may include software programs, is required to assist with interpretation

- Closer partnerships between institutional and subject repository staff will be essential to building engagement with the designated community 


\section{Libraries without walls 7}

\section{Roles, Rights, Responsibilities, Relationships - 2}

-Institutional repositories have a fundamental argument for sustainability because of their position within an institution

-They are frequently located in departments with a persistent service orientation - i.e. libraries or information services - whose main role is the management of information

-Many scholars care primarily about their discipline or domain, before their institution

- Scholars who have hybrid skills in domain science and data/information handling will be a valuable resource in the future 
The next stage in the evolutionary growth of librarians...

Re-emergence of the scholar librarian?

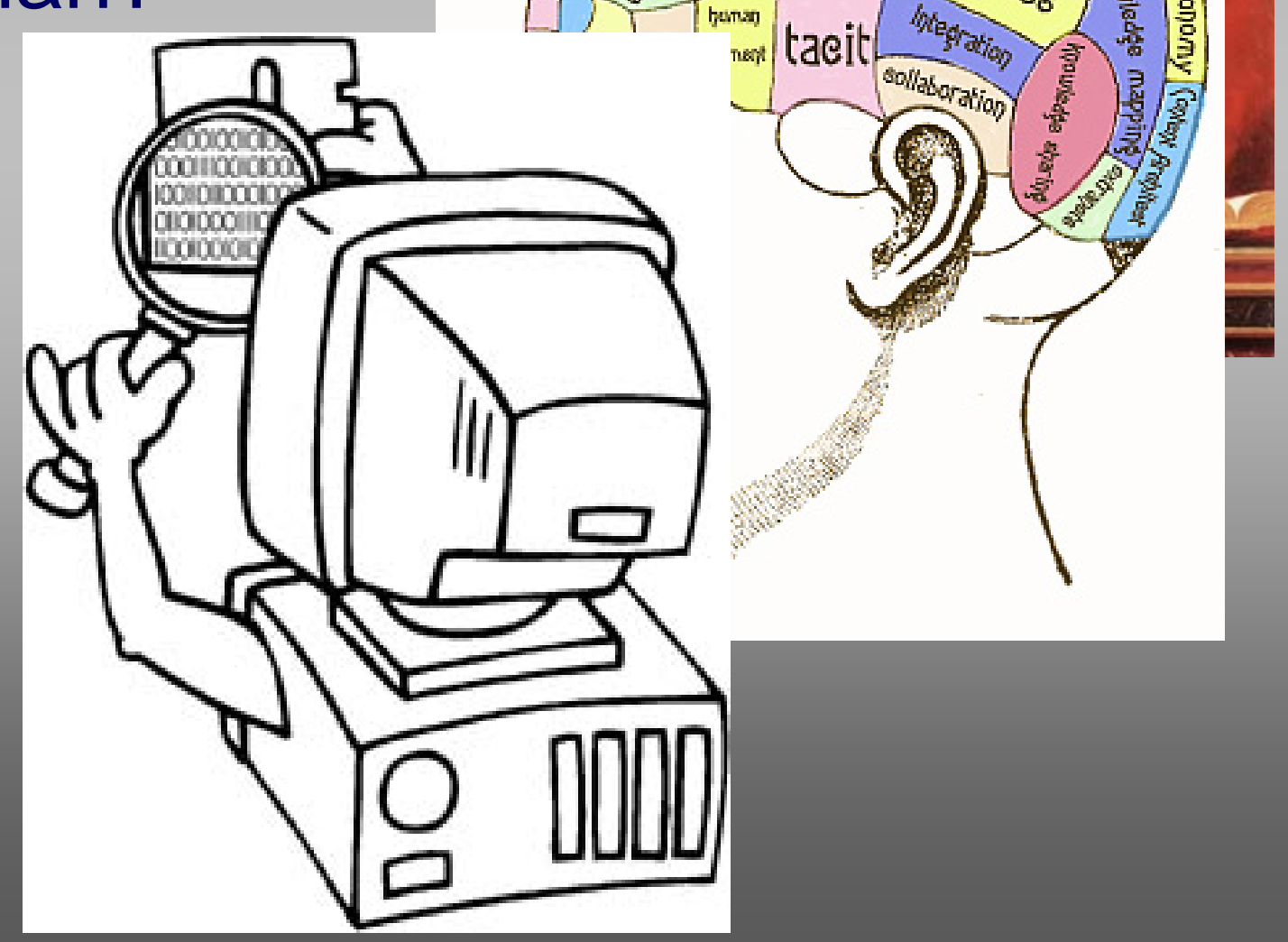




\section{Conclusion}

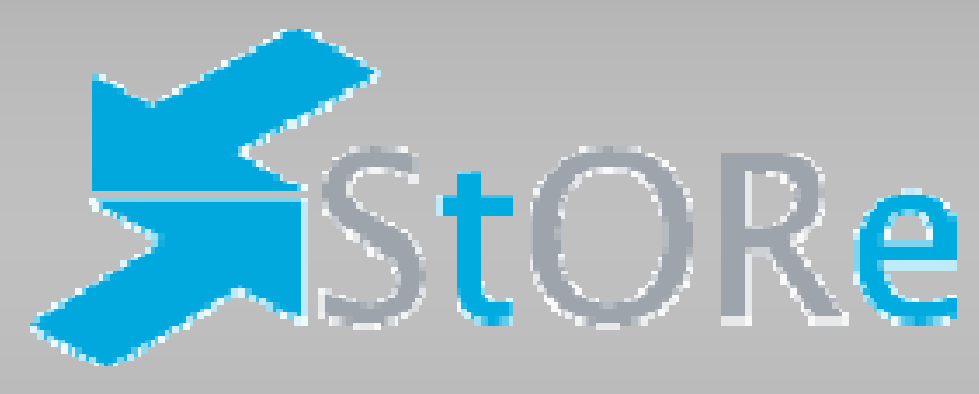

Thank you 